\title{
A Century of American Viticulture
}

\author{
Paul E. Read and Sanjun Gu \\ University of Nebraska, Lincoln, NE 68583-0724
}

To review the work reported on a crop that "comes to us out of the abyss of antiquity" (Winkler, 1965) is a Herculean task impossible to accomplish within the scope of this review. Therefore, to honor the first century of the American Society for Horticultural Science (ASHS), this review will focus on selected viticulture literature published from 1903 to 2002. Of necessity, some topics will be omitted or only briefly treated.

The culture of grapevines (Vitis spp.) apparently began in the Transcaucasus region, principally between the Black and Caspian Seas, where the classical wine and table grape Vitis vinifera reputedly originated. Greek legend attributes Dionysus with introducing the art of grape growing. Archeological discoveries demonstrate that the fruits were consumed as early as the Bronze Age and fossil leaves and seeds date to the Tertiary period (Basserman-Jordan, 1923, Columbia Encyclopedia, 2002; Kirchheimer, 1938). Undoubtedly, additional archeological discoveries will add to our knowledge of ancient grape culture.

European grapes reportedly were introduced to the eastern colonies of North America by Lord Delaware in 1619 and to the western shore of the continent even earlier by the conquistadors, with Cortez, then Governor of Mexico, ordering grapes to be planted about 1525 (Bailey, 1912; Bancroft, 1883; Hedrick, 1907). More than $70 \%$ of Vitis species are native to North America, with nearly all Vitis species originating in the Northern Hemisphere. Of the approximately 60 species, Bailey (1934) lists 23 and Hortus Third (1976) includes 21 cultivated species. Hedrick (1907) lists over 1400 varieties of cultivated American grape species. A long and storied history of American grape growing continued into the 20th century, replete with successes and failures; a clearly successful trend of growth of the industry is apparent in Fig. 1. The most notable of the failures was the inability of early colonial Americans to grow Vitis vinifera in the eastern colonies, now the eastern states of the U.S. Phylloxera [Phylloxera vitifoliae (Fitch)] is well documented as a primary cause of this failure leading Winkler (1965) to state that "there has never been a commercially successful vineyard of vinifera grapes east of the Rocky Mountains and north of Texas." No doubt Winkler would be taken aback by the flourishing vinifera industry in eastern states such as New York and Virginia as we enter the 21 st century.

Early 20th century viticulture was greatly influenced by the aforementioned failures due to phylloxera, and to a lesser degree, by diseases such as powdery mildew and downy mildew, to which Vitis vinifera was not resistant. As a result, much attention was given to adapting North American species and hybrids to viticulture in the eastern United States. Contributions to the early Proceedings of the American Society for Horticultural Science reflected a bias toward such research because of the large number of ASHS members from states east of the Rocky Mountains. Nearly 300 articles on grapes and their culture were included in the Proceedings, with over 100 articles on topics such as vineyard management, fruit development, trellising and canopy management, and the influence of such factors on fruit quality. By contrast, only about 20 articles of a similar nature were published in the Journal of the American Society for Horticultural Science since its inception in 1969. Similarly, nearly 50 contributions that focused on breeding and related matters are found in the Proceedings, with only about 10 published in the Journal. Although part of the disparity in such numbers can be attributed to the initiation of other journals (e.g., HortScience, HortTechnology, Journal of the American Society of Enology and Viticulture), it is clear that early 20th century viticulture was slanted heavily toward vineyard management and grape breeding and improvement. Fertilizer practices, physiology and cold hardiness, rootstocks, propagation and pest management became more important in the 1930s and 1940s. Reports on weed management and the use of plant growth regulating chemicals came to the fore following World War II; biotechnology, genetic engineering and transformation of grapes are recent developments that are chronicled also in ASHS and other publications, mostly since 1990 .

\section{VINEYARD MANAGEMENT AND RELATED RESEARCH}

It is difficult to categorize the research of the early 1900s because many early papers in the Proceedings encompassed multiple subjects. For example, the first paper on grapes to appear in the Proceedings was contributed by S.A. Beach (1903), one of the founders of ASHS, and the first words of its title were Grape Breeding, but the paper presented correlations of fruit size with seed size and the relationship of seed size to germination rate and seedling vigor (Beach, 1903). T.V. Munson (1905) perhaps is best known for his role in demonstrating that vinifera scions grafted onto North American rootstocks could resist phylloxera. However, he made important contributions to grape breeding and showed that all native North American species were dioecious (Booth, 1911; Munson, 1905). Booth (1911) used this information and other observations to clarify that grape cultivars generally considered to be of native species' origin ( $V$. labrusca) such as 'Catawba' and 'Concord' ('Bull's Concord') are indeed hybrids, probably owing their trait of perfect flowers to an admixture of $V$. vinifera parentage. The dominance of 'Concord' in the industry is borne out by the fact that many of the papers published in the first half or more of the 20th century were based on this cultivar.

\section{PRUNING AND TRAINING GRAPEVINES}

Pruning and training grapevines received a great deal of attention throughout the century, from the notes on pruning and training of 'Concord' grapes by Colby and Vogele (1924) in which the authors compared four training systems and five levels of buds left following pruning, to the description and development of the Geneva Double Curtain trellis system for 'Concord' grapevines (Shaulis et al., 1966a, 1966b). Reports on the effects of pruning on growth and production (Clark, 1925) and of fruiting on vine and root growth (Chandler and Heinecke, 1925) are notable. Both demonstrated that fruit load or its absence, and certain pruning treatments, materially affected both vine and root growth; root growth was suppressed more than vine growth by fruit load. The latter report employed use of a planimeter to determine leaf area, which in some cases was also reduced by fruit load when compared to the vines from which flower clusters had been removed. Interestingly, the total dry matter produced by a given leaf area was larger for vines that were allowed to fruit than for vines that had flowers removed, perhaps the "removal of materials from the leaves to the fruits must tend to increase photosynthesis" (Chandler and Heinecke, 1925). Less severe pruning, combined with excess flower cluster removal, improved the fruiting of 'Muscat of Alexandria' grapes (Winkler, 1927).

Many viticulturists have recognized the importance of pruning and training vines to maximize light interception and facilitate harvest and other management operations, in addition to creating an environment conducive to good air circulation and thus reduce the likelihood of disease incidence. Late or delayed pruning was shown to delay bud break and bloom date, but had no effect on date of fruit ripening (Loomis, 1939). Colby and Tucker (1928) compared different levels of pruning severity on growth of terminals and laterals, and on fruit yield. They found that vigor was greater for shoots arising after severe pruning, but yield was reduced by limiting the bud number left to produce yield. Pinching the terminals of 'Champanel' grapevines led to increased yield, but a lower weight of prunings when compared with orthodox pruning (Loomis, 1949). Numerous training systems were used in early research, including the Munson, Fan, Kniffin and Chatauqua trellis systems (Colby and Voegele, 1924). Colby (1929) later proposed a six-cane Kniffin trellis for 'Concord' under Illinois conditions of highly fertile soils and excessive vine vigor; perhaps this was a portent of later trellis systems for 'Concord', such as the Geneva Double Curtain (Shaulis et al., 1966a).

A number of studies evaluating vine growth characteristics and 


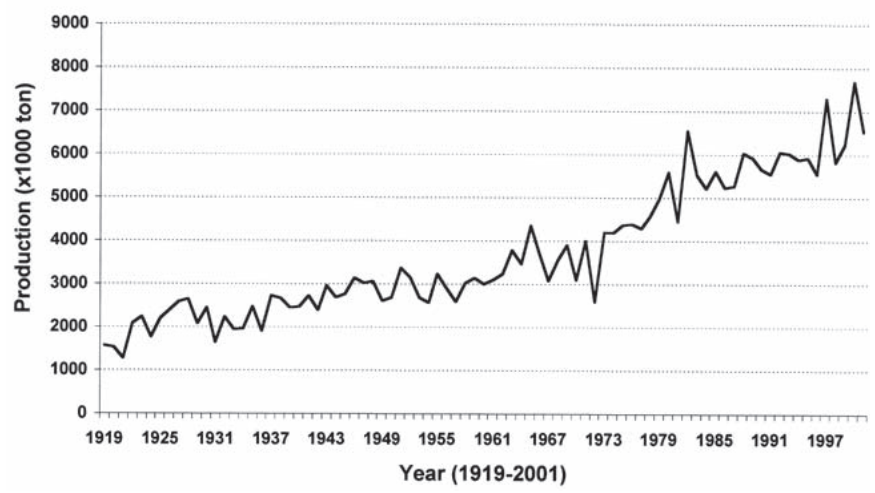

Fig. 1. Production of grapes for fresh consumption of the United States (19192001). Data from the annual agricultural statistics. USDA and National Agricultural Statistics Service.

fruit yield were conducted in the 1920s. Partridge (1926) studied the relationship of growth in the year before fruiting on yield in the following year and found that the most productive canes had a diameter of about one-fourth inch. Angelo (1927) concurred, although he found that productiveness of 'Concord' increased for canes up to $0.9 \mathrm{~cm}$ in diameter. He further noted that upper canes were more productive per bud than lower canes. Relative fruitfulness of primary versus secondary buds of 'Concord' was studied in depth by Wiggans (1926). Because a frost killed $25 \%$ to $40 \%$ of the primary buds it was feasible to determine precisely whether shoots arose from primary or secondary buds. His findings demonstrated a great advantage for primary buds which produced $300 \%$ to $400 \%$ more fruit and $135 \%$ to $190 \%$ larger clusters than for secondary buds, although there was no difference in berry size.

Plant spacing can have a significant impact on vine growth and yield of grapes. Shaulis and Kimball (1955) conducted research on plant spacing with 'Concord' grapes at two New York state locations. When close plant spacing was used, differences in growth and yield did not appear until the fifth growing season, when vine growth was restricted by close spacing. In subsequent seasons, the closest-spaced vines were obviously the smallest, with little to no differences observed among spacings ranging from 76 to $104 \mathrm{ft}^{2} / v i n e$. Balanced pruning is often practiced, wherein the number of buds retained is dictated by the weight of prunings. For 'Concord' in New York, a formula is to leave 30 buds for the first pound of prunings plus 10 buds for each additional pound or partial pound of prunings. However, in Washington State, the formula for 'Concord' is adjusted to 50 plus 10 (Clore and Brummond, 1961). Their work and the subsequent report by Shaulis et al (1966b) confirm that light and shoot exposure are critically important factors in grape yield and fruit quality. They further demonstrate that the fruitfulness of the subsequent year depends on exposure of exterior shoots to light and that systems that open the canopy, e.g., Geneva Double Curtain, provide for more exterior shoots and facilitate mechanical harvesting (Shepardson et al., 1962).

Only limited work was done in the early years on composition and movement of substrates, possibly because of the lack of analytical equipment and the laborious nature of the work. However, Richey and Bowers (1924) working with 'Concord' found no appreciable translocation of carbohydrates from the vines to the roots during the dormant season and that a larger root system was established on newly planted vines if two shoots were allowed to grow rather than only one. Winkler (1932) studied the lateral movement of elaborated foods and concluded that it took 16 leaves to produce food for an average cluster of table grapes.

Roots also received a moderate degree of attention throughout the century, beginning with Colby's (1922) "Preliminary Report of the Root Systems of Grape Varieties", in which he found that feeding roots were found from a depth of 6 inches and that it was often necessary to use a pick (to examine the roots) from $4 \mathrm{ft}$ down. Harmon and Snyder (1934) studied root distribution on grafted vines that averaged about 25 years old, growing near Fresno, Calif., on sandy loam soil with depths to hardpan ranging from 32 to 88 inches (average 55 inches). Total root weights varied from about 4,000 to $>18,000 \mathrm{~g}$. The differences appeared to be loosely correlated with rootstock and to lesser degree, with scion. Wiggans (1926) also reported roots at a depth of 30 feet on grapes grown on a loess soil. Later, Doll (1955) studied 6-year-old 'Concord' grape roots on a loess soil because of a lack of response to fertilizer applications and found very extensive root development, reaching $14.5 \mathrm{ft}$ in depth and over $24 \mathrm{ft}$ in horizontal spread.

\section{FERTILIZERS AND NUTRIENT ANALYSIS}

Numerous experiments with grape fertilization have taken place in the past century. A few of the most interesting are noted here, with special emphasis on methods of analysis employed to bring a more scientific approach to fertilizer practice. Stene (1935) reported a considerable amount of fluctuation with regard to yields, but concluded that if potassium was omitted, a significant yield reduction resulted. Boron deficiency was observed on grapevines grown on sandy soils in South Carolina, with subsequent correction achieved through applications of borax (Scott, 1940). Chlorosis in 42 varieties of American grapes was studied by Bryant and Beach (1940) on soil of $\mathrm{pH} 8.2$ in the top 6 inches and 8.5 at the 18 inch depth. They found considerable variation among varieties in terms of high $\mathrm{pH}$-induced chlorosis symptoms, ranging from resistant or chlorosis-free (e.g., 'Beta', 'Delaware', 'Elvira') through medium chlorosis ('Concord', 'Niagara', 'Catawba') to severe or very severe chlorosis ('Moore Early', 'Diamond', 'Champagne'). Zinc deficiency (Cook and Mitchell, 1958) and salinity (Ehlig, 1960) are common problems in California vineyards, with zinc chelate sprays helpful in correcting zinc deficiency symptoms.

Attempts to quantify tissue nutrient content in relation to fertilizer practice became a major thrust in the middle part of the century. Webster and Cross (1938) analyzed leaves of several grape varieties that exhibited uneven coloration in autumn, but concluded that carbohydrate and nitrogen composition could not be the cause of the unusual coloration exhibited by 'Sheridan' and 'Concord' leaves. At about the same time, Myers, et al (1939) conducted quantitative spectrographic analyses of eight elements in 'Delaware' grape leaves. They were able to correlate higher calcium and magnesium levels with complete fertilizer and mulch treatments, but found no differences in leaf mineral content when comparing complete fertilizer with nitrate of soda treatment. Ulrich (1943a) working with 'Petite Sirah' and 'Mataro' vines in California, followed up on the concept of petiole analysis introduced by Lagatu and Mausne (1934) and further described by Thomas (1937) by comparing potassium content of leaf petioles and blades with soil analyses to determine the potassium needs of grapevines. In this research, yields were positively correlated with the potassium content of petioles, but not with soil tests, and petiole potassium content was better than leaf blade content with regard to the potassium status of the vines. Similarly, Ulrich (1943b) further reported that petiole nitrate levels were a better indicator of vine nitrogen status than leaf blade nitrate content. Later work in California (Cook and Kishaba, 1956) and New York (Shaulis and Kimball, 1955) confirmed the value of petiole analysis as a criterion for determining nutrient status of the vine and for directing fertilizer applications. Although work by Fleming (1963) suggested that plant sap analysis might have some potential for determining nutrient status of the vine, petiole analysis has remained the standard for several decades, possibly because of the ease of collecting samples and its accuracy.

\section{TOXIC COMPOUNDS}

As early as 1932, concern was expressed for accumulation of toxic spray residues in grapes (Lutz and Runner, 1932). Lead arsenate commonly was applied for control of grape berry moth, causing worries that arsenical residue could be considerably above the tolerance. Although such chemicals are no longer used, it is interesting to note the level of concern and the attempts to alleviate the problem. Washing the fruit with a dilute solution of hydrochloric acid $(0.33 \%)$ was the only method tested that reduced residues satisfactorily. Furthermore, toxicity to apple roots on trees treated with lead arsenate was observed by Childers (1940), with arsenic more toxic than lead. Subsequent work with sodium arsenate showed that grape roots were more sensitive to arsenic than were roots of apple or rye, suggesting that arsenic-containing sprays not only were a concern as residue on fruit, but that damage 
to the health of the vineyard could also result. In addition, Brewer et al (1957) found that fluoride toxicity could occur on leaves in vineyards located near heavy industry. They also noted fluoride accumulation in the fruit from such vineyards, so modern concerns about pesticide residue are certainly not a new problem.

\section{VINEYARD PRACTICES AFFECT FRUIT QUALITY}

Many studies have been conducted implicating vineyard management and specific practices relative to the characteristics of the grape berries harvested. Winkler $(1928,1930)$ examined the influence of berry thinning on berry size, color and sugar content, as well as the relation of leaf number to berry size and quality of table grapes. Weight of 'Tokay' grapes was improved by thinning and the berries colored sooner than those from nonthinned vines; earlier coloring was desirable because early fruit commanded a higher price. Sixteen leaves per shoot of girdled 'Muscat' and 'Malaga' grapes produced larger fruit with higher sugar content than shoots with 27 leaves on plants that had not been girdled. Girdling table grapes became a common practice, with berry size and improved quality reported by several researchers (Dhillon and Singh, 1949; Jacob, 1928; Weaver, 1952). Juice quality has also been shown to be influenced by the method of vine training (Webster and Cross, 1936). They compared fruit from the top and bottom wires of a Kniffin trellis system with that from a Munson trellis system. For 'Concord', the Kniffin top wire fruit and the fruit from the Munson system were similar in total sugar and total acidity and had higher sugar and acidity than fruit from the Kniffin bottom wire. However, acidity levels were lower for fruit of 'Niagara' trained to a Munson trellis than for top or bottom wire Kniffin 'Niagara' fruit. The same authors had earlier conducted chemical analyses of grape juice from 28 varieties of American and hybrid grapes (Webster and Cross, 1935a). They also conducted an in-depth evaluation of the use of the refractometer to study sugar content of grape juice (Webster and Cross, 1935b). Although they point out slight discrepancies related to use of the refractometer, it remains in common use today. Interestingly, juice quality continues to be a topic of importance. Morris (1998) reaffirms the importance of cultivar, climate and site factors; harvesting system and post-harvest handling all affect juice quality characteristics.

\section{COLD HARDINESS}

Horticulturists world-wide seem to take pleasure in attempting to grow plants not suited to inhospitable climates or under challenging conditions. Viticulturists too are examples of this syndrome; they try to grow cultivars and species under less than ideal conditions in order to have the fruit of the vine for eating directly or processing into wine, juice and other products. In addition to attempting to circumvent earlier-mentioned challenges of disease and phylloxera, problems posed by extremes of winter low temperatures and rapidly fluctuating temperatures in autumn and spring pose significant obstacles to viticulture. Angelo (1922) presented a paper on the extent of recovery by several grape varieties following spring frosts. This author points out that in contrast to many tree fruits where frost may completely eliminate that year's crop, the grapevine has the ability, because of its compound bud containing primary, secondary and tertiary buds, to produce a partial crop following damage to its primary buds. Winkler (1933) reported on various treatments applied to 'Thompson Seedless' and 'Malaga' vines following a frost event, but found no treatment to alleviate the damage when compared to the control (no treatment). He did, however, discredit the long-held opinion that a toxin produced in frosted tissue would translocate to injure the nondamaged part. Root damage to 'Beta' grape grown in Minnesota and tested under controlled low temperatures was reported by Brierly and Angelo (1934). They found that the roots were severely injured or killed at $-12^{\circ} \mathrm{F}$. Cold winter temperature damage to buds of several varieties of grapes was also evaluated and the varieties were placed into six classes of relative bud damage (Clark, 1936). Such studies were the progenitors of further studies of cold hardiness in the latter part of the 20th century.

Plant cold hardiness has been defined as the ability of a plant or plant part to survive (Fuchigami, 1996) or resist freezing conditions (Soule, 1985). Cold hardiness of grapevines is very important in grape production areas with cold winters (Howell and Shaulis, 1980) and Vitis species or cultivars vary greatly in their cold hardiness (Bourne and Moore, 1991a, 1991b; Miller et al., 1988a; Wolfe and Brown, 1986). There also were differences in cold hardiness of canes within a 'Concord' canopy (Wolpert and Howell, 1985).

Grape cold hardiness is usually expressed by the cold hardiness of primary buds, which is reasonable because it reflects the winter survival and production potential of grapevines (Gu et al., 2001). To quantify the cold hardiness of primary buds, LT50 (the low temperature lethal to $50 \%$ of primary buds), LTE (low temperature exotherm) analysis, Qlt (lethal temperature coefficiency), and CF (chlorophyll fluorescence) techniques, together with physical observation in vineyards have been employed (Clark et al., 1996; Gu, 1999; Jiang and Howell, 2002; Lipe et al., 1992; Wample et al., 1990; Wolf and Cook, 1994).

Cold hardiness of primary buds is affected by fluctuating temperatures (causing acclimation or deacclimation) in winter and spring or fall (Hubackova, 1996; Gu et al., 2001, 2002). It is also affected by the degree of bud dormancy. For instance, hardiness of two muscadine grape cultivars and V. labrusca 'Mars' increased from November to January (Clark et al., 1996).

Cultural practices may or may not influence cold hardiness. Fallpruned vines showed a higher percentage of bud death from freezing than the nonpruned control under field conditions (Wolpert and Howell, 1984). Midwinter pruning, however, had little effect on bud cold hardiness (Wample, 1994). In another report Wample et al (1993) demonstrated the insignificant effect of nitrogen fertilization on bud cold hardiness of 'White Riesling' grapes. Stergios and Howell (1977) reported little effect of trellis height on cold hardiness, although hand defoliation in fall and pruning severity did affect cold hardiness on 'Concord' grapes in Michigan.

\section{PROPAGATION}

Propagation of grapevines by hardwood cuttings has long been regarded as a relatively straightforward and successful practice. The need to graft vinifera grapes onto phylloxera-resistant rootstocks, along with the recalcitrance to rooting of cuttings of some species and cultivars, led to a number of investigations noted here. For example, Calma and Richey (1931) studied growth of 'Concord' cuttings with regard to position on the cane from which cuttings were taken, and vigor and composition of the canes. They attributed success in rooting of the cuttings primarily to the food reserves present in the cutting, which were correlated with cane vigor and position of the cutting. Later, Harmon (1944) demonstrated the efficacy of treating difficult to root cuttings with indolebutyric acid (IBA). Since muscadine grape cuttings were considered difficult to root, Cowart and Savage (1944) attempted treatment with auxin analogs, indoleacetic acid (IAA), IBA, and naphthaleneacetic acid (NAA) with limited success. A special rooting box was devised by Magoon and Dix (1940) to propagate cuttings by a method similar to air layering.

Jacob (1932) used various heat treatments to stimulate bench grafts of grape, with a modest degree of success. He also tried treatment of the grafts with mercury compounds commonly employed for cereal seed treatment. These efforts were largely unsuccessful, although the compounds did control the growth of molds. Bud grafting methods were studied at the USDA laboratory in Fresno, Calif., with the Tbud method commonly in use for fruit tree propagation proving to be adapted to grape propagation (Harmon and Snyder, 1939; Snyder and Harmon, 1940). They also demonstrated the importance of the season of the year on bud-graft success. Best results were obtained from April to early August.

Propagation research was stimulated in the last quarter of the century by the advent of micropropagation. Pool and Powell (1975) produced shoots in vitro from 'Concord'grapevines, demonstrating the importance of cytokinins to the process. Two years later, Krul and Worley (1977) were able to produce adventitious embryos in vitro from callus cultures of 'Seyval', while Spiegel-Roy et al. (1985) produced plantlets from grape cultivars with abortive embryos and seeds. Likewise, Stamp et al (1990) developed improved systems for organogenesis from grape leaves, while Lee and Wetzstein (1990) showed that the recalcitrant muscadine grape could indeed be propagated in vitro. Shoot-tip culture 
in vitro has also been demonstrated to eliminate Pierce's disease bacteria from muscadine grapes (Robacker and Chang, 1992). These developments ultimately provided the basis for producing intact plants when genetic engineering approaches were employed in later years. These concepts will be discussed further in the sections on Biotechnology and What of the Future? below.

\section{WEED MANAGEMENT}

Competition from weeds has long been a problem for grape growers, especially when establishing new vineyards. Corn stover mulches were compared with clean cultivation in research by Magoon et al (1944). They found greater fruit yield for 'Concord' and 'Ontario', but not for 'Delaware', under clean cultivation and suggested that results could have been different if other mulches had been used. In agreement with this, we have found no advantage for clean cultivation versus prairie hay or wood chip mulch with 'Edelweiss' grapes (Read, unpublished). Chemical weed control became important in the middle of the century, although weed oil treatments by Williams (1951) did not consistently result in increased yields, though they did increase pruning weights. Meanwhile, serious injury to grapevines from 2,4-dicholorophenoxy acetic acid (2,4-D) sprays began to be reported following that chemical's becoming widely used on monocot crops (Clore and Bruns, 1953). As had been reported for eastern vineyards, 2,4-D was found to cause serious damage to 'Concord' grown in Washington State. Greenhouse studies with simazine and diuron showed that root application could cause serious injury depending on variety, suggesting that care must be taken when applying herbicides in the vineyard (Lider et al., 1966). Research continues in the arena of weed management, wherein herbicides, mulches, and both conventional and alternative weed control strategies may be used (Pool et al., 1990), with integrated weed management approaches as a goal.

\section{PLANT GROWTH REGULATORS}

Following the discovery of gibberellins and the successful implementation of chemicals for weed control, chemical companies began screening chemicals for regulation of plant growth. Use of such chemicals for manipulating grape plants and fruit began to be investigated in the middle of the century. Pentzer (1940) attempted to duplicate the success found in apple in reducing premature fruit drop through application of NAA to reduce shatter in grape clusters. Likewise, auxin analogs and other chemicals were employed by Overcash (1955) to overcome uneven ripening of 'Concord' in Mississippi, while Weaver (1953) used 4-chlorophenoxyacetic acid (4-CPA) to enhance fruit development in 'Thompson Seedless' and 'Black Corinth'. Weaver (1954) also reported on the use of several growth regulating chemicals for thinning grapes. He noted that it was difficult to achieve appropriate thinning because fruit injury could occur and the clusters often were under-thinned or over-thinned. However, $0.1 \% \alpha$-NAA thinned compact 'Zinfandel' clusters to about the proper degree. The use of the potassium salt of gibberellic acid (Gibrel) or similar formulations is now a standard practice for loosening clusters and enlarging berries of 'Thompson Seedless'. Numerous papers were published in the 1950s and 1960s presenting results of such treatments (Stewart and Ching, 1957; Stewart and Halsey, 1957; Stewart et al., 1958). Treatment of clusters with $100 \mathrm{ppm}$ Gibrel resulted in longer and heavier clusters, heavier and longer berries, and an increase in sugar content of the berries. Following the successes with 'Thompson Seedless', gibberellin treatments were used on other cultivars. Pratt and Shaulis (1961) increased fruit set and induced parthenocarpy on 'Fredonia' treated with $100 \mathrm{ppm}$ gibberellic acid $\left(\mathrm{GA}_{3}\right)$. Dipping 'Delaware' clusters in $100 \mathrm{ppm} \mathrm{\textrm {GA } _ { 3 }}$ also caused up to $96 \%$ seedless berries and led to earlier ripening and lower sugar-acid ratios in the seedless berries (Clore, 1965). Christodoulou et al (1968) reconfirmed typical GA effects when the compound was applied at bloom: looser, elongated clusters and significant berry elongation. An early Journal of ASHS paper by Weaver and Pool (1969) discusses other growth regulating chemicals in relation to abscission and shoot growth of $V$. vinifera. Treatment with 4-CPA before applications of Ethrel (an ethylene-releasing compound) and morphactin reduced the effectiveness of these chemicals in causing abscission. Morphactin-induced abscission had been reported earlier by Weaver and Pool (1968) in an effort to compare morphactins with abscisic acid and ethephon for inducing berry abscission. Other growth regulating chemicals have been investigated in recent years, including daminozide, thidiazuron, and phenylurea compounds. McCaskill and Morris (1977) studied the yield and quality of 'Concord' grapes treated with daminozide, while Funt and Tukey (1977) reported on cluster development and yield of 'Concord' treated with gibberellic acid and daminozide, with the chemicals counteracting each other to some degree. Work with plant growth regulating chemicals continues. For example Fellman et al. (1991) induced seedlessness in 'Swenson Red' with GA 3 cluster dips at or near anthesis and Lu et al. (1997) have recently shown that seedlessness could be produced by applications of $\mathrm{GA}_{3}$ to 'Triumph' muscadine grapes.

\section{ROOTSTOCKS}

Grafting vines as a means of propagation was known as early as the 2nd century BC (Cato in his treatise De agri cultua). The use of rootstocks however, was not popularized until 1880 when it became the only effective method to combat the devastating root louse phylloxera (Coombe, 1999). California grape growers have been using rootstocks for over 100 years (Foott et al., 1989). Rootstock trials were first reported in the Proceedings in 1934 by Snyder and Harmon, in which they indicated the influence of scions on Dog Ridge rootstock.

Grape phylloxera historically has been among the worst threats to modern viticulture because of its potential to destroy vineyards by attacking vine roots. It was first found in California in 1873, about ten years after its detection in Europe. Between 1885 and 1900, a tremendous effort to develop rootstocks was made after the discovery by European investigators of the resistance to the insect of native American Vitis species (Lider et al., 1995).

Besides resistance to phylloxera, rootstocks confer resistance or tolerance to other organisms, including root nematodes (Magoon and Magness, 1937; McCarthy and Cirami, 1990), fungal diseases (Brown et al., 1999a; Cristinzio et al., 2001; Staudt, 1997) and bacterial diseases (Loomis, 1965; Sule and Burr, 1998). Some rootstocks also showed tolerance or resistance to abiotic stresses, such as alkalinity (Bavaresco et al., 1992, 1993), salinity (Leon et al., 1969; Walker et al., 2000, 2002), drought (Carbonneau, 1985), temperature extremes (Miller et al., 1988a, 1988b; Striegler and Howell, 1991), and flood (Pongraz, 1983; Striegler et al., 1993).

The way rootstocks interact with scions is still unclear. The primary change after grafting is the direct replacement of the root system. Root anatomy and morphology, development and distribution of the root system may be different among rootstock species (Richards, 1983). The main roots of $V$. rupestris form narrow angles with the vertical axis and can penetrate deeply, while those of $V$. riparia form wide angles and remain relatively shallow (Perold, 1927). Also, there are differences in root density (Daulta and Chauhan, 1980) and distribution (Harmon and Snyder, 1934; Perry and Lyda, 1983) among grapevine species or cultivars.

Changes imparted by rootstocks may indirectly affect vine physiology, such as influencing photosynthesis and water use efficiency (During, 1994; Koblet et al., 1997; Williams and Smith, 1991) and mineral uptake (Cook and Lider, 1964; Ruhl, 2000). Such changes eventually will be reflected in vine growth, yield, and fruit and wine qualities.

Although much of the world's viticulture is now based primarily on grafting, wherein the scion is a cultivar of V. vinifera and the rootstock is either a North American Vitis species or an interspecific Vitis hybrid (Weaver, 1976), rootstocks may not provide significant advantage over own-rooted vines in areas without phylloxera (Boselli et al., 1992). Reynolds and Wardle (2001) concluded that own-rooted vines worked as well as grafted ones in regions such as the Pacific northwestern U.S. and British Columbia.

Use of rootstocks involves grafting. The methods for grafting grapevines were well established before 1960. Bench grafting of grapevines, was first introduced in the Proceedings in 1932 by Jacob and proved to be more effective than field grafting (Harmon and Weinberger, 1963; Snyder and Harmon, 1944). Greenwood grafting was reported by Harmon and Snyder in 1948. Cleft grafting, notch grafting, bark 
grafting, side-whip grafting, wedge grafting, and field budding were well illustrated by Alley in 1964 and 1975 (Alley, 1964, 1975a, 1975b, 1975c). Depending on the stock and scion cultivars, incompatibilities sometimes take place (Jacob, 1943). For example, Emperor, Molinera, Palomino and Aramon were incompatible on the rootstock Berlandieri $\mathrm{x}$ Rupestris 57-Richter .

\section{IMPROVEMENT OF GRAPE CULTIVARS}

The various attempts by early colonials to grow European grapes in America failed (Hedrick, 1914), due to the scourge of phylloxera, short growth periods, cold temperatures and perhaps the following of empirical European practices. This led to the employment of native American species in grape breeding programs. For example, early cultivars of 'Cape Grape', 'Catawba', 'Alexander', 'Isabella', and even 'Concord' were from native American species (Booth, 1911).

There are about 60 species of Vitis, mainly found in the temperate zones of the Northern Hemisphere, which are almost equally distributed between America and Asia (Mullins et al. 1992). Among them, $V$. cinerea, V. riparia, V. labrusca, and V. aestivalis have been reported to be used in grape breeding programs. Barrett (1957) pointed out that V. cinerea should be desirable in grape breeding. 'Cythiana' or 'Norton', a cultivar selected from $V$. aestivalis, is the most widely grown cultivar in Missouri. Vitis rotundifolia, the muscadine grape, has a long history in southern US breeding programs (Lane, 1997). The oldest representative cultivar is 'Scuppernong' (Woodroof, 1934). Vitis labrusca, including the famous 'Concord' grape, has been used in interspecific hybrids with various cultivated $V$. vinifera for grape juice, jelly, fresh fruit and wine (Remaily, 1987). Vitis riparia, the most widely distributed species, is very adaptable (Remaily, 1987). It serves as one of the basic materials in E.P. Swenson's private grape breeding program (Swenson, 1985) and in the University of Minnesota's breeding programs (Luby, 1991). The very hardy cultivar 'Beta' resulted from a cross between V. riparia and 'Concord' (Brierley and Angelo, 1934; Luby, 1991).

Grapevine improvement methods were well documented by Alleweldt and Possingham (1988) and Ramming (2002). Clonal selection and cross-breeding are the two major categories. The application of genetic transformation in grape breeding was documented in detail by Ramming (2002) and is discussed elsewhere in this review. Besides diploids, tetraploid grapes were also given much attention (Olmo, 1943a, 1952) for enlarged berries, thick bunch stems and dark green leaves. Most of this work was done on table grapes, although tetraploid Muscadine grapes were also investigated (Dunstan 1964; Fry, 1963). Methods for determining the ploidy level are laborious since grape chromosomes are very small and very few cell divisions are present in the apex. Feulgen spectrophotometry of fluorometry is simple and accurate (Saurer and Antcliff, 1969), although more advanced techniques such as flow cytometry are now available.

Literature related to grape breeding accounted for close to $20 \%$ of the contributions on grapes in the Proceedings of the American Society for Horticultural Science, while in HortScience, about 80 out of 178 grape papers are grape breeding or cultivar related. The first breeding paper to appear in the Proceedings was by Beach (1903). After that, some basic breeding concepts, such as chromosome counts (Sax, 1929), self-fertility (Dearing, 1917), parthenocarpy and seed abortion (Pearson, 1932; Olmo, 1934), fruiting habit (Partridge, 1922; Pickett, 1927), pollen storage, fertilization methods and hastening of fruit production (Anthony, 1914; Snyder and Harmon, 1936; Olmo, 1943 b), and disease resistance (Demaree, 1937) were investigated. Some preliminary breeding results were reported (Auchter and Whitehouse, 1923; Snyder, 1931; Stout, 1936; Wellington, 1932,1936; Yeager, 1936). The study of inheritance of some traits, however, began to take place much later; examples include sex determination (Barrett, 1966; Negi and Olmo, 1971); inheritance of major fruit colors (Barritt and Einset, 1969); inheritance of resistance to Pierce's disease (Mortensen, 1968) and downy mildew (Brown et al., 1999b); and dioecy and pollen dimorphism (Kevan et al., 1985, 1988). Since HortScience was initiated in 1966, over 57 new releases of grape cultivars have been reported.

Numerous grape breeders have made major contributions to the development of the modern grape industry in the United States. Intending no disrespect to the accomplishments of these researchers, especially the notable contributions of Olmo (1943 a, 1943b, 1944 a, 1944b, 1952), the significant work of Thomas V. Munson (1843-1913) and Elmer P. Swenson are briefly profiled here.

Munson was a pioneer in American viticulture who made important contributions in classification, breeding, and cultural practices (Tarara and Hellman, 1990). His breeding work was intended primarily to combine the disease resistance and climatic adaptability of native American species with the fruit qualities of the classic V. vinifera cultivars. He produced over 300 grape cultivars, which have served not only for their grape production, but also as valuable breeding materials. For example, 'Carman' was a widely grown grape in northern Texas and two of Munson's famous rootstock cultivars, 'Dog Ridge' and 'Ramsey', are still used in modern viticulture worldwide. The French government awarded him the Legion of Honor's "Chevalier du Merite Agricole" in 1885 for his outstanding work with rootstocks.

Munson died in 1913 and another grape breeder was born-Elmer Swenson, of Wisconsin. Swenson was a farmer and self-taught viticulturist and grape breeder. Inspired by his grandfather's small vineyard and Munson's book Foundation of American Grape Culture, Swenson used mostly V. riparia (Swenson, 1985; Luby, 1991) and some other native Vitis species in his breeding schemes. Some important cultivars released by Swenson are Edelweiss, Swenson Red, Esprit, Kay Gray, Lacrosse, St. Croix, St. Pepin, and Prairie Star . Many of these hybrids form the basis of the resurgence of viticulture in the upper Midwest. Now over 90 years of age, Swenson is still active in his vineyard and shares the hybrids that he has developed over the years with anyone who may be interested.

\section{BIOTECHNOLOGY}

Although the promise of biotechnology for grapevine improvement has yet to be fully realized, much progress has been made to date. Agrobacterium tumefaciens-mediated transformation has been attempted by several research teams and gradual progress has been achieved (Baribault et al., 1990; Colby et al., 1991; Mullins et al., 1990; Scorza et al., 1996). Scorza et al (1996) partially overcame difficulty in regeneration by first using microprojectile bombardment of 'Thompson Seedless' somatic embryos, followed in $2 \mathrm{~h}$ by co-cultivation with Agrobacterium for 2 weeks. Microprojectile bombardment alone was reported by Hebert et al (1993) to show promise with embryogenic suspension cultures of 'Chancellor'. Later work from the same laboratory (Kikkert et al., 1996) led to regenerated transgenic plants from germinated somatic 'Chancellor' embryos. Xue at al (1999) succeeded in producing transformed plants of five different grape rootstocks using the bombardment-Agrobacterium approach used by Scorza et al (1996), incorporating the plant virus genes, grapevine fan-leaf virus (GFLV) and grapevine leafroll-associated closterovirus (GLRaV-3). Although the transformation efficiency has not been very high, there is much reason for optimism that significant advances in grape transformation can be made in the 21 st century.

Another arena of biotechnology that has made great strides in the last two decades is the use of molecular technologies for identification of grape genotypes, clones and their ancestors. Work by Meredith's group (Bowers and Meredith, 1996; Riaz et al., 2002) has demonstrated that genetic similarities and differences can be identified by use of restriction fragment-length polymorphism (RFLP) and other similar technologies. Similarly, Xu and Bakalinsky (1996) used sequence characterized amplified region DNA markers to identify grape rootstocks. In addition, Striem et al (1996) identified molecular markers related to seedlessness in grape genotypes and Lamboy and Alpha (1998) employed simple sequence repeats for DNA fingerprinting of grape accessions.

Transformation, use of molecular markers, engineering grapes for disease and stress resistance and to enhance fruit and wine quality, details of micropropagation, and a series of related topics are presented in the recent book Molecular Biology and Biotechnology of the Grapevine (Roubelakis-Angelakis, 2001).

\section{WHAT OF THE FUTURE?}

Exciting prospects lie ahead for the burgeoning and ever-expanding grape and wine industry. As with most horticultural fields, the 
growth of the scientific endeavor is global and parallels the growth of the industry. Many areas of sciences, both old and new, should have significant impact on 21 st century viticulture. Some of the following are projected to have significant influence.

1. Application of new technologies to further the understanding of physiology and genetics of grapevines. For example, those technologies mentioned under Biotechnology will continue to be applied to identify grape genotypes and parents. In addition, grapes will likely be created that are genetically modified to possess resistance to diseases and other stresses, along with modifications affecting fruit and wine quality. But, will the consumer and historically tradition-rich industry, especially the wine industry, accept genetically modified grapes (GMG)?

2. Use of technologies, such as nuclear magnetic resonance imaging (NMR) will prove useful in expanding knowledge about dormancy and other physiological phenomena (Fennell and Line, 2001).

3. Remote and global information systems (GIS) will become routine technologies for identifying appropriate sites for grape production and for recognizing stresses in the vineyards (Lang et al 2000). With such technologies it will be feasible to detect stresses caused by disease and moisture deficits, thus enabling timely decisions for pesticide applications and irrigation to the vineyard.

4. A health-conscious public will continue to demand more information about the health benefits of grapes and their products. Blevins and Morris (1997) have reviewed the health benefits of grape juice and wine; undoubtedly both the medical and horticultural research communities will continue to monitor and pursue this arena of scientific endeavor.

5. Organic grape production will continue to receive attention. The aforementioned concern about health by the public will stimulate further research aimed at reducing the amount and increasing the safety of chemical inputs applied to the vineyards. Comparisons of phylloxera damage to organic and conventionally managed vineyards is but one recent example (Lotter et al., 1999), while several major wineries have initiated programs geared toward organic grape and wine production.

6. Practical viticulture research will continue to make valuable contributions to modern grape production practices. It is clear that this flourishing industry includes a large number of dedicated and talented professionals that are well prepared to continue the rich tradition exemplified by the research contributions of the past century.

\section{Literature Cited}

Alleweldt, G. and J.V. Possingham. 1988. Progress in grapevine breeding. Theo. Appl. Gen. 75:669-673.

Alley, C. J. 1964. Grapevine propagation I. A comparison of cleft and notch grafting; and, bark grafting at high and low levels. Amer. J. Enol. Viticult. 15:214-217.

Alley, C. J. 1975a. Improved field budding of grapevines. Calif. Agr. 29:6-8.

Alley, C. J. 1975b. Research note: grapevine propagation VII. The wedge graft -A modified notch graft. Amer. J. Enol. Viticult. 26:105-108.

Alley, C. J. 1975c. Research note: grapevine propagation VIII. The side whip graft, an alternative method to the split graft for use on stocks $2-4 \mathrm{~cm}$ in diameter. Amer. J. Enol. Viticult. 26:109-112.

Angelo, E. 1922. The recovery of grape vines when the young shoots are killed by spring frosts. Proc. Amer. Soc. Hort. Sci.19:29-32.

Angelo, E. 1927. A study of the fruiting behavior of Concord canes of various diameters. Proc. Amer. Soc. Hort. Sci. 24:155-156.

Anthony, R. D. 1914. Methods and results in grape breeding. Proc. Amer. Soc. Hort. Sci. 11:81-86.

Auchter, E. C. and W. E. Whitehouse. 1923. Preliminary report on grape breeding in Maryland. Proc. Amer. Soc. Hort. Sci.20:114-116.

Bailey, L.H. 1912. Sketches of the evolution of our native fruits. MacMillan, New York

Bailey, L.H. 1934. The species of grape peculiar to North America. Gentes Herbarum 3:151-244.

Bancroft, H.H. 1883. History of Mexico. vol. 3. The History Co. San Francisco.

Baribault, T.J., K.G.M. Skene, P.G. Cain, and N. Steel Scott. 1990. Transgenic grapevines: Regeneration of shoots expressing $\beta$-glucuronidase. J. Expt. Bot. 41:1045-1049.

Barrett, H.C. 1957. Vitis cinerea as a source of desirable characters in grape breeding. Proc. Amer. Soc. Hort. Sci.70:165-168.
Barrett, H.C. 1966. Sex determination in a progeny of a self pollinated staminate clone of Vitis. Proc. Amer. Soc. Hort. Sci. 88:338-340.

Barritt, B.H., and J. Einset. 1969. The inheritance of three major fruit colors in grapes. J. Amer. Soc. Hort. Sci. 94:87-88.

Basserman-Jordan, F. 1923. Geschichte des Weinbaus. Frankfurt am Main, Frankfurter Verlags-Anstalt A.G., Volume I.

Bavaresco, L., M. Fregoni, and P. Fraschini. 1992. Investigations on some physiological parameters involved in chlorosis occurrence in grafted grapevines. J. Plant Nutr. 15:1979-1807.

Bavaresco, L., P. Fraschini, and A. Perino.1993. Effect of the rootstock on the occurrence of lime-induced chlorosis of potted Vitis vinifera L. cv. 'Pinot Blanc'. Plant and Soil 157:305-311.

Beach, S. A. 1903. Grape breeding; Size, weight and specific gravity of the seed as correlated with germination and the vigor of the seedling. Proc. Amer. Soc. Hort. Sci. 1:42-53.

Blevins, J.M. and J.R. Morris. 1997. Health benefits of wine and grape juice. HortTechnology 7:228-233.

Booth, N.O. 1911. A suggestion in regard to the history of grape growth in America. Proc. Amer. Soc. Hort. Sci. 8:105-112.

Boselli, M., M. Fregoni, A. Vercesi, and B. Volpe. 1992. Variation in mineral composition and effects on the growth and yield of Chardonnay grapes on various rootstocks. Agricoltura Ricerca 14:138-139.

Bourne, T.F. and J.N. Moore. 1991a. Cold hardiness in grape cultivar development. Fruit Var. J. 45:26-28.

Bourne, T.F. and J.N. Moore. 1991b. Primary bud hardiness of four genotypes of grapes in Arkansas. J. Amer. Soc. Hort. Sci. 116:835-837.

Bowers, J.E. and C.P. Meredith. 1996. Genetic similarities among wine grape cultivars revealed by restriction fragment-length polymorphism (RFLP) analysis. J. Amer. Soc. Hort. Sci. 121:620-624.

Brewer, R.F., R.C. McColloch, and F.H. Sutherland. 1957. Fluoride accumulation in foliage and fruit of wine grapes growing in the vicinity of heavy industry. Proc. Amer. Soc. Hort. Sci. 70:183-187.

Brierley, W.G. and E. Angelo. 1934. Winter killing of the roots of the Beta grape. Proc. Amer. Soc. Hort. Sci.31:114-118.

Brown, M.V., J.N. Moore, P. Fenn, and R.W. McNew. 1999a. Evaluation of grape germplasm for downy mildew resistance. Fruit Var. J. 53:22-29.

Brown, M.V., J.N., Moore, R. W. McNew, M. V. Brown, and P. Fenn. 1999b. Inheritance of downy mildew resistance in table grapes. J. Amer. Soc. Hort. Sci. 124:262-267.

Bryant L.R. and G.A. Beach. 1940. A preliminary study of chlorosis in american grapes. Proc. Amer. Soc. Hort. Sci. 38:395-396.

Calma, V.C. and H. W. Richey. 1931. Growth of Concord grape cuttings in relation to vigor, chemical composition on the cane. Proc. Amer. Soc. Hort. Sci. 28:131-136.

Carbonneau, A. 1985. The early selection of grapevine rootstocks for resistance to drought conditions. Amer. J. Enol. Viticult. 36:195-198.

Chandler, W.H. and A.J. Heinecke. 1925. Some effects of fruiting on the growth of grape vines. Proc. Amer. Soc. Hort. Sci.22:74-80.

Childers, N.F. 1940. The toxicity of certain spray chemicals to the roots of apple, grape, rye, and corn. Proc. Amer. Soc. Hort. Sci. 38:157.

Christodoulou, A.J., R.J. Weaver, and R.M. Pool. 1968. Relation of gibberellin treatment to fruit-set, berry development, and cluster compactness in Vitis vinifera grapes. Proc. Amer. Soc. Hort. Sci. 92:301-310.

Clark, J.H. 1925. Some effects of pruning on grape production. Proc. Amer. Soc. Hort. Sci. 22:80-84.

Clark, J.H. 1936. Injury to the buds of grape varieties caused by the low temperatures. Proc. Amer. Soc. Hort. Sci. 34:408-413.

Clark, J.R., T.K. Wolf, and M. Warren. 1996. Thermal analysis of dormant buds of two Muscadine grape cultivars and of Vitis labrusca L. 'Mars'. HortScience 31:79-81.

Clore, W.J. 1965. Responses of Delaware grapes to gibberellin. Proc. Amer. Soc. Hort. Sci. 87:259-263.

Clore, W.J. and V.F. Bruns. 1953. The sensitivity of Concord grape to 2,4-D. Proc. Amer. Soc. Hort. Sci. 61:125-134.

Clore, W.J. and V.P. Brumnund. 1961. The effect of vine size on the production of Concord grapes balanced pruned. Proc. Amer. Soc. Hort. Sci. 78: 239-244.

Colby, A.S. 1922. Preliminary report of the root system of grape varieties. Proc. Amer. Soc. Hort. Sci. 19:191-194.

Colby, A.S. 1929. The training of certain grape varieties to the 6-cane Kniffin system. Proc. Amer. Soc. Hort. Sci. 26:274-277.

Colby, A.S. and A.C. Vogele. 1924. Notes on pruning and training Concord grapes in Illinois. Proc. Amer. Soc. Hort. Sci.21:384-387.

Colby, A.S. and L.R. Tucker. 1928. Growth and fruit studies in the grape. Proc. Amer. Soc. Hort. Sci. 25:210-216.

Colby, S.M., A.M. Juncosa, and C.P. Meredith. 1991. Cellular differences in Agrobacterium susceptibility and regenerative capacity restrict the development of transgenic grapevines. J. Amer. Soc. Hort. Sci. 116:356-361. 
Columbia Encyclopedia. 2002. The Columbia encyclopedia. 6th ed. Columbia Univ. Press.

Cook, J.A. and T. Kishaba. 1956. Petiole analysis as a criterion of nitrogen needs in California vineyards. Proc. Amer. Soc. Hort. Sci. 68:131-140.

Cook, J.A. and L.A. Lider. 1964. Mineral composition of blooming time grape petiole in relation to rootstock and scion variety behavior. Proc. Amer. Soc. Hort. Sci. 84:243-254.

Cook, J.A. and F.G. Mitchell. 1958. Screening trails of chelated zinc materials toward the correction of zinc deficiency in Vinifera grapevine. Proc. Amer. Soc. Hort. Sci. 72:149-157.

Coombe, B. 1999. Grafting, p. 323-324. In: J. Robinson (ed.). The Oxford companion to wine. 2nd ed. Oxford Univ. Press, New York.

Cowart,F.F. and E.F. Savage. 1944. The effect of various treatments and methods of handling upon rooting of Muscadine grape cuttings. Proc. Amer. Soc. Hort. Sci. 44:312-314.

Cristinzio, G., C. Iannini, G. Scaglione, and M. Boselli. 2001. Effect of rootstocks on Botrytis cinerea susceptibility of Vitis vinifera cv. Falanghina. Adv. Hort. Sci. 14:83-86.

Daulta, B.S. and C.S. Chauhan. 1980. Variety variation in root growth of some grape cultivars (V. vinifera). Prog. Hort. 12:37-39.

Dearing, C. 1917. The production of self-fertile Muscadine grapes. Proc. Amer. Soc. Hort. Sci. 14:30-34.

Demaree, J.B., I.W. Dix, and C.A. Magoon. 1937. Observations on the resistance of grape varieties to black rot and down mildew. Proc. Amer. Soc. Hort. Sci. 35:451-460.

Dhillon, A.S. and L. Singh. 1949. The influence of thinning and ringing on the cropping and quality of grapes and the vigor of grapevines. Proc. Amer Soc. Hort. Sci. 53:263-268.

Doll, C.C. 1955. Studies of Concord grape roots in Loess soil. Proc. Amer. Soc. Hort. Sci. 65:175-182.

Dunstan, R.T. 1964. Hybridization of Euvitis x Vitis rotundifolia: Backcrosses to Mucadines. Proc. Amer. Soc. Hort. Sci. 84:238-242.

During, H. 1994. Photosynthesis of ungrafted and grafted grapevines: effects of rootstock genotype and plant age. Amer. J. Enol. Viticult. 45:297-299.

Ehlig, C.F. 1960. Effects of salinity on four varieties of table grapes grown in sand culture. Proc. Amer. Soc. Hort. Sci. 76:323-331.

Fellman, C.E., Hoover, P.D. Ascher, and J. Luby. 1991. Gibberellic acid-induced seedlessness in field-grown vines of 'Swenson Red' grape. HortScience 26:873-875.

Fennell, A. and M.J. Line. 2001. Identifying differential tissue response in grape (Vitis riparia) during induction of endodormancy using nuclear magnet ressonance imaging. J. Amer. Soc. Hort. Sci. 126:681-688.

Fleming, J.W. 1963. Analysis of Concord grape plant sap for diagnosis of nutrient status. Proc. Amer. Soc. Hort. Sci. 83:384-387.

Foott, J.H., C.S. Ough, and J.A. Wolpert. 1989. Rootstock effects on wine grapes. Calif. Agr. 43:27-29.

Fry, B.O. 1963. Production of tetraploid Muscadine (V. rotundifolia) grapes by gamma radiation. Proc. Amer. Soc. Hort. Sci. 83:388-394.

Fuchigami, L.H. 1996. Cold hardiness. In: F.B. Salisbury (ed.). Units, symbols, and terminology for plant physiology: Areference for presentation of research results in the plant science. Oxford Univ. Press, New York.

Funt, R.C. and L.D. Tukey. 1977. Influence of exogenous daminozide and gibberellic acid on cluster development and yield of the Concord grape. J. Amer. Soc. Hort. Sci. 102:509-514.

$\mathrm{Gu}, \mathrm{S} .1999$. Lethal temperature coefficient - a new parameter for interpretation of cold hardiness. J. Hort. Sci. Tech. 74:53-59.

Gu, S., P. Ding, and S. Howard. 2002. Effect of temperature and exposure time on cold hardiness of primary buds during early, mid, and late dorman season in 'Concord', 'Norton', 'Vignoles', and 'St. Vincent' grapevines. J. Hort. Sci. Tech. 77:635-639.

Gu, S., S. Dong, J. Li, and S. Howard. 2001. Acclimation and deacclimation of primary bud cold hardiness in 'Norton', 'Vignoles', and 'St. Vincent' grapevines. J. Hort. Sci. Tech. 76:655-660.

Harmon, F.N. 1944. Influence of indolebutyric acid on the rooting of grape cuttings. Proc. Amer. Soc. Hort. Sci. 42:383-388.

Harmon, F.N. and E. Snyder. 1934. Grape rootstock distribution study. Proc. Amer. Soc. Hort. Sci. 32:370-373.

Harmon, F.N. and E. Snyder. 1939. The "T" bud method, an aid to grape propagation. Proc. Amer. Soc. Hort. Sci. 37:663-665.

Harmon, F.N. and E. Snyder. 1948. Some factors affecting the success of green wood grafting of grapes. Proc. Amer. Soc. Hort. Sci. 52:294-295.

Harmon, F.N. and J.H. Weinberger. 1963. Bench grafting trials with Thompson seedless grape on various rootstocks. Proc. Amer. Soc. Hort. Sci. 83: 379-383.

Hebert, D., J.R. Kikkert, F.D. Smith, and B.I. Reisch. 1993. Optimization of biolistic transformation of embryogenic grape cell suspensions. Plant Cell Rpt. 12(10):585-589.

Hedrick, U.P. 1907. The grapes of New York. Part 2. 15th Annu. Rpt. Dept. of
Agr., State N.Y., J.B. Lyon, State Printer

Hedrick, U.P. 1914. Recent work with Vitis vinifera in New York. Proc. Amer. Soc. Hort. Sci. 11:77-81.

Hortus Third. 1976. A concise dictionary of plants cultivated in the United States and Canada. MacMillan, New York.

Howell, G.S. and N. Shaulis. 1980. Factors influencing within-vine variation in the cold resistance of cane and primary bud tissues. Amer. J. Enol. Viticult. $31: 158-161$.

Hubackova, M. 1996. Dependence of grapevine bud cold hardiness on fluctuations in winter temperatures. Amer. J. Enol. Viticult. 47:100-102

Jacob, H.E. 1928. Some responses of the seedless varieties of Vitis vinifera to girdling. Proc. Amer. Soc. Hort. Sci. 25:223-229.

Jacob, H.E. 1932. Stimulation of grape bench grafts. Proc. Amer. Soc. Hort Sci. 29:356-358.

Jacob, H.E. 1943. Examples of incompatibility between grape varieties and rootstocks. Proc. Amer. Soc. Hort. Sci. 41:201-203.

Jiang, H. and G.S. Howell. 2002. Applying chlorophyll fluorescence technique to cold hardiness studies of grapevines. Amer. J. Enol. Viticult. 53:210-217

Kevan, P.G., D.C.A. Blades, U. Posluszny, and J.D. Ambrose. 1988. Pollen dimorphism and dioecy in Vitis aestivalis. Vitis 27:143-146.

Kevan, P.G., R.W. Longair, and R.M. Gadawiski. 1985. Pollen dimorphism and dioecy in Vitis ripara (Vitaceae). Canadian Journal of Botany 63: 2263-2267.

Kikkert, J.R., D. Hebert, P.G. Wallace, M.J. Striem, and B.I. Reisch. 1996. Optimization of biolistic transgenic plantlets of 'Chancellor' grapevine (Vitis sp.) from biolistic transformation of embryogenic cell suspensions. Plant Cell Rep. 15(5):311-316.

Kirchheimer, F. 1938. Aus der Geschichte der Rebengewachse. Wein u. Rebe 20:188-192.

Koblet, W., M. Keller, and M. C. Candolfi-Vasconcelos. 1997. Effects of training system, canopy management practices, crop load and rootstock on grapevine photosynthesis. Acta Horticulturae 427:133-140.

Krul, W.R. and J.F. Worley. 1977. Formation of adventitious embryos in callus cultures of 'Seyval', a French hybrid grape. J. Amer. Soc. Hort. Sci. 102: 360-363.

Lagatu, H. and L. Mausne. 1934. Recherches sur le diagnostic foliar. Annales de l'Ecole Nationale d'Agriculture de Montpellier 22:257-306.

Lamboy, W.F. and C.G. Alpha. 1998. Using simple sequence repeats (SSRs) for DNA fingerprinting germplasm accessions of grape (Vitis L.) species. J. Amer. Soc. Hort. Sci. 123:182-188.

Lane, R. 1997. Breeding Muscadine and southern bunch grapes. Fruit Varieties J. 51(3):144-148.

Lang, N.S., J. Silbernagel, E.M. Perry, R. Smithyman, L. Mills, and R.L. Wample. 2000. Remote image and leaf reflectance analysis to evaluate the impact of environmental stress on grape canopy metabolism. HortTech. 10:468-474

Lee, N. and H. Y. Wetzstein. 1990. In vitro propagation of muscadine grape by axillary shoot proliferation. J. Amer. Soc. Hort Sci. 115:324-329.

Leon, B., C. F. Ehlig. and R. A. Clark. 1969. Effects of grape rootstocks on chloride accumulation in leaves. J. Amer. Soc. Hort. Sci. 94:584-590.

Lider, I. A., A. H. Lange, and O. A. Leonard. 1966. Susceptibility of grape, Vitis vinifera L., varieties to root application of Simazine and Diuron. Proc. Amer. Soc. Hort. Sci. 88:341-345

Lider,L.A., M. A. Walker, and J. A. Wolpert. 1995. Grape rootstocks in California vineyards: the changing picture. Acta Horticulturae 388, 13-18

Lipe, W., N. L. Baumhardt, C.W. Wendt, and D.J. Raybush. 1992. Differential thermal analysis of deacclimating Chardonnay and Cabernet Sauvignon grape buds as affected by evaporative cooling. Amer. J. Enol. Viticult. 43: 355-361.

Loomis, N. H. 1939. Note on grape foliation as affected by time of pruning. Proc. Amer. Soc. Hort. Sci. 37:653-654.

Loomis, N. H. 1949. The effect of different methods of spur pruning upon the production and growth of Muscadine grapes. Proc. Amer. Soc. Hort. Sci. 54:183-185.

Loomis, N. H. 1965. Further trials of grape rootstocks in Mississippi. Proc. Amer. Soc. Hort. Sci. 86:326-328

Lotter, D.W., J. Granett, and A.D. Omer. 1999. Differences in grape phylloxerarelated grapevine root damage in organically and conventionally managed vineyards in California. HortScience 34:1108-1111

Lu, J., O. Lamikanra, and S. Leong. 1997. Induction of seedlessness in 'Triumph muscadine grape (Vitis rotundifolia Michx.) by applying gibberellic acid. HortScience 32:89-90.

Luby, J.J. 1991. Breeding cold-hardy fruit crops in Minnesota. HortScience 26:507-512

Lutz, J.M. and G.A. Runner. 1932. Studies on the removal of arsenical spray residue from grapes. Proc. Amer. Soc. Hort. Sci. 29:345-349.

Magoon, C.A. and I.W. Dix. 1940. On aerial propagation of grapes. Proc. Amer Soc. Hort. Sci. 38:388-392. 
Magoon, C.A. and J.R. Magness. 1937. Investigation on the adaptability of grape rootstocks to Gulf Coast conditions. Proc. Amer. Soc. Hort. Sci. 35: $466-470$.

Magoon, C.A., I.W. Dix, and J.R. Magness. 1944. Mulch versus clean cultivation as affecting vineyard performance. Proc. Amer. Soc. Hort. Sci. 45: 280-282.

McCarthy, M.G. and R.M. Cirami. 1990. The effect of rootstocks on the performance of Chardonnay from a nematode-infested Barossa Valley vineyard Amer. J. Enol. Viticult. 41:126-130.

McCaskill, D.R. and J.R. Morris. 1977. Effect of daminozide on yield and quality of 'Concord' grapes (Vitis labrusca L.) in Arkansas. J. Amer. Soc. Hort. Sci. 102:8-10.

Miller, D.P., G.S. Howell, and R.K. Striegler. 1988a. Cane and bud hardiness of selected grapevine rootstocks. Amer. J. Enol. Viticult. 39:55-59.

Miller, D.P., G.S. Howell, and R.K. Striegler. 1988b. Cane and bud hardiness of own-rooted white Riesling and scion of white Riesling and Chardonnay grafted to selected rootstocks. Amer. J. Enol. Viticult. 39:60-86.

Morris, J.R. 1998. Factors influencing grape quality. HortTechnology 8: $471-478$.

Mortensen, J.A. 1968. The inheritance of resistance to Pierce's disease in Vitis. Proc. Amer. Soc. Hort. Sci. 92:331-337.

Mullins, M.G., F.C.A. Tang, and D. Facciotti. 1990. Agrobacterium mediated genetic transformation of grapevines: Trangenic plants of Vitis rupestris Scheele and buds of Vitis vinifera L. Bio/Technology 8:1041-1045.

Mullins, M.G., A. Bouquet, and L. Williams 1992. Biology of the grapevines. Cambridge Univ. Press. New York.

Munson, T.V. 1905. Improvement in quality in grapes. Proc. Amer. Soc. Hort. Sci. 2:19-24.

Myers, A.T., B.C. Brunstetter, I.W. Dix, and C.A. Magoon. 1939. A quantitative spectrographic determination of eight elements in young leaves of the Delaware grape. Proc. Amer. Soc. Hort. Sci. 37:645-649.

Negi, S.S. and H.P. Olmo. 1971. Conversion and determination of sex in Vitis vinifera $\mathrm{L}$. Vitis 9:265-279.

Olmo, H.P. 1934. Bud mutation in the Vinifera grape. I. Parthenocarpic Sultanina. Proc. Amer. Soc. Hort. Sci. 31:119-121.

Olmo, H.P. 1943a. Breeding new tetraploid grape varieties. Proc. Amer. Soc. Hort. Sci. 41:225-227.

Olmo, H.P. 1943b. Storage of grape pollen. Proc. Amer. Soc. Hort. Sci. 41: 219-224.

Olmo, H.P. 1944a. Pollination of the Almeria grape. Proc. Amer. Soc. Hort. Sci. 42:401-406.

Olmo, H.P. 1944b. Selection for fruit color in the Emperor grape. Proc. Amer. Soc. Hort. Sci. 42:395-400.

Olmo, H.P. 1952. Breeding tetraploid grapes. Proc. Amer. Soc. Hort. Sci. 59: 285-290.

Overcash, J.P. 1955. Some effects of certain growth-regulating substances on the ripening of Concord grapes. Proc. Amer. Soc. Hort. Sci. 65:54-57.

Partridge, N.L. 1922. Further observations on the fruiting habit of the Concord grape. Proc. Amer. Soc. Hort. Sci. 19:180-183.

Partridge, N.L. 1926. The use of the growth-yield relation in field trials with grapes. Proc. Amer. Soc. Hort. Sci. 23:131-135.

Pearson, H.M. 1932. Parthenocarpy and seed abortion in Vitis vinifera. Proc. Amer. Soc. Hort. Sci. 29:169-175.

Pentzer, W.T. 1940. Studies on the shatter of grapes with special reference to use of solution of naphthalene acetic acid to prevent it. Proc. Amer. Soc. Hort. Sci. 38:397-399.

Perold, A.I. 1927. A treatise on viticulture. Macmillan, London.

Perry, R.L. and S.D. Lyda. 1983. Root distribution of four Vitis cultivars. Plant Soil 71:63-74.

Pickett, W.F. 1927. Further study on the fruiting habit of the grape. Proc. Amer. Soc. Hort. Sci. 24:151-154.

Pongraz, D.P. 1983. Rootstocks for grapevines. David Phillip Publ., Cape Town.

Pool, R.M. and L.E. Powell. 1975. The influence of cytokinins on in vitro shoot development of 'Concord' grape. J. Amer. Soc. Hort. Sci. 100:200-202.

Pool, R.M., R.M. Dunst, and A.N. Lakso. 1990. Comparison of sod, mulch, cultivation and herbicide floor management practices for grape production in nonirrigated vineyards. J. Amer. Soc. Hort. Sci. 115:872-877.

Pratt, C. and N.J. Shaulis. 1961. Gibberellin-induced parthenocarpy in grapes Proc. Amer. Soc. Hort. Sci. 77:322-330.

Ramming, D.W. 2002. Methods of developing improved raisin cultivars. In V.E. Petrucci and C.D. Clary (eds.). A treatise on raisin production, processing and marketing. Malcolm Media Press. Clovis, Calif.

Remaily, G.W. 1987. Diversity of North American species of Vitis. Plant Gen. Resour. Nwslt. 71:25-30.

Reynolds, A.G. and D.A. Wardle. 2001. Rootstocks impact vine performance and fruit composition of grapes in British Columbia. HortTechnology 11: 419-427.
Riaz, S., K.E. Garrison, G.S. Dangl, J.M. Boursiquot, and C.P. Meredith. 2002. Genetic divergence and chimerism within ancient asexually propagated wine grape cultivars. J. Amer. Soc. Hort. Sci. 127:508:514.

Richards, D. 1983. The grape root system. Hort. Rev. 5:127-168.

Richey, H.W. and H.A. Bowers. 1924. Correlation of root and top growth of the Concord grape and translocation of elaborated plant food during the dormant season. Proc. Amer. Soc. Hort. Sci. 21:33-39.

Robacker, C.D. and C.J. Chang. 1992. Shoot-tip culture of muscadine grape to eliminate Pierce's disease bacateria. HortScience 27:449-450.

Roubelakis-Angelakis, K. (ed.). 2001. Molecular biology and biotechnology of the grapevine. Kluwer Academic Publ., Dordrecht.

Ruhl, E.H. 2000. Effect of rootstocks and $\mathrm{K}^{+}$supply on $\mathrm{pH}$ and acidity of grape juice. Acta Horticulturae 512:31-37.

Saurer, W. and A.J. Antcliff. 1969. Polyploid mutants in grapes. HortScience 4:226-227.

Sax, K. 1929. Chromosome counts in Vitis and related genera. Proc. Amer. Soc. Hort. Sci. 26:32-33.

Scorza, R., J.M. Cordts, D.J. Gray, D. Gonsalves, R.L. Emershad, and D.W. Ramming. 1996. Producing transgenic 'Thompson Seedless' grape (Vitis vinifera L.) plants. J. Amer. Soc. Hort. Sci. 121:616-619.

Scott, L.E. 1940. An instance of boron deficiency in the grape under field conditions. Proc. Amer. Soc. Hort. Sci. 38:375-378.

Shaulis, N. and K. Kimball. 1955. Effect of plant spacing on growth and yield of Concord grapes. Proc. Amer. Soc. Hort. Sci. 66:192-200.

Shaulis, N., E.S. Shepardson, and T.D. Jordan. 1966a. The geneva double curtain for Concord grapes. N.Y. Agr. Expt. Sta. Bul. 811.

Shaulis, N., H. Amberg, and D. Crowe. 1966b. Response of Concord grapes to light, exposure and Geneva double curtain training. Proc. Amer. Soc. Hort. Sci. 89:268-280.

Shepardson, E.S., H.E. Studer, N.J. Shaulis, and J.C. Moyer. 1962. Mechanical grape harvesting, research progress and developments at Cornell. Agr. Eng. 43:66-71.

Snyder, E. 1931. A preliminary report on the breeding of Vitis grape varieties. Proc. Amer. Soc. Hort. Sci. 28:125-130.

Snyder, E. and F. N. Harmon. 1934. Vinifera grape scion influence on Dog Ridge stock. Proc. Amer. Soc. Hort. Sci. 32:374-375.

Snyder. E. and F. N. Harmon. 1936. Hastening the production of fruit in grape hybridizing work. Proc. Amer. Soc. Hort. Sci. 34:426-427.

Snyder, E. and F. N. Harmon. 1940. Time limits of the grape bud-graft method. Proc. Amer. Soc. Hort. Sci. 38:373-374.

Snyder, E. and F. N. Harmon. 1944. A comparison of bench-grafted and fieldgrafted vinifera grape vines. Proc. Amer. Soc. Hort. Sci. 42:389-390.

Soule, J. 1985. Glossary for horticultural crops. John Wiley and Sons, New York.

Spiegel-Roy, P., N. Sahar, J. Baron, and U. Lavi. 1985. In vitro culture and plant formation from grape cultivars with abortive ovules and seeds. J. Amer. Soc. Hort. Sci. 110:109-112.

Stamp, J.A., S.M. Colby, and C.P. Meredith. 1990. Improved shoot organogenesis from leaves of grape. J. Amer. Soc. Hort. Sci. 115:872-877.

Staudt, G. 1997. Evaluation of resistance to grapevine powdery mildew (Uncinula necator (Schw.) Burr., anamorph Oidium tuckeri Berk.) in accessions of Vitis species. Vitis 36:151-154.

Stene, A.E. 1935. Fertilizer treatments of grapes. Proc. Amer. Soc. Hort. Sci. 33:453-455.

Stergios, B.G. and G.S. Howell. 1977. Effects of defoliation, trellis height, and cropping stress on the cold hardiness of Concord grapevines. Amer. J. Enol. Viticult. 28:34-42.

Stewart, W.S., D. Halsey, and F.T. Ching. 1958. Effect of potassium salt of gibberellic acid on fruit growth of Thompson seedless grapes. Proc. Amer. Soc. Hort. Sci. 72:165-169.

Stewart, W.S. and D.D. Halsey. 1957. Effects of gibberellic acid sprays on Thompson Seedless grapes. Lasca Leaves 7:80.

Stewart, W.S. and F.T. Ching. 1957. Horticultural research notes on gibberellic acid. Lasca Leaves 7:23-28.

Stout, A.B. 1936. Breeding for hardy seedless grapes. Proc. Amer. Soc. Hort. Sci. 34:416-420.

Striegler, R.K. and G.S. Howell. 1991. The influence of rootstock on the cold hardiness of Seyval grapevines I. Primary and secondary effects on growth, canopy development, yield, fruit quality and cold hardiness. Vitis 30:1-10.

Striegler, R.K., G.S. Howell, and J.A. Flore. 1993. Influence of rootstock on the response of Seyval grapevines to flooding stress. Amer. J. Enol. Viticult. 44:313-319.

Striem, M.J., G.B. Hayyim, and P. Spiegel-Roy. 1996. Identifying molecular genetic markers associated with seedlessness in grape. J. Amer. Soc. Hort. Sci 121:758-763.

Sule, S. and T.J. Burr. 1998. The effect of resistance of rootstocks to crown gall (Agrobacterium spp.) on the susceptibility of scions in grape vine cultivars. Plant Pathol. 47:84-88. 
Swenson, E.P. 1985. Wild Vitis riparia from northern US and Canada-Breeding source for winter hardiness in cultivated grapes - A background of the Swenson hybrids. Fruit Var. J. 39(1)28-31.

Tarara, J.M. and E.W. Hellman. 1990. The Munson grapes - A rich germplasm legacy. Fruit Var. J. 44(3)127-130.

Thomas, W. 1937. Foliar diagnosis: Principles and practices. Plant Physiol. 12:571-599.

Ulrich, A. 1943a. Nitrate content of grape leaf petioles as an indicator of the nitrogen status of the plant. Proc. Amer. Soc. Hort. Sci. 41:213-217.

Ulrich, A. 1943b. Potassium content of grape leaf petioles and blades contrasted with soil analysis as an indicator of the potassium status of the plant. Proc Amer. Soc. Hort. Sci. 41:204-212.

Walker, R.B., D.H. Blackmore, R.P. Clingeleffer, and C.L. Ray. 2002. Rootstock effects on salt tolerance of irrigated field-grown grapevines (Vitis vinifera L. cv. Sultana). I. Yield and vigor inter-relationships. Austral. J. Grape Wine Res. 8:3-14.

Walker, R.R., P.E. Read, and D.H. Blackmore. 2000. Rootstock and salinity effects on rates of berry maturation, ion accumulation and color development in Shiraz grapes. Austral. J. Grape Wine Res. 6:227-239

Wample, R.L. 1994. A comparison of short- and long-term effects of mid-winte pruning on cold hardiness of Cabernet Sauvignon and Chardonnay buds. Amer. J. Enol. Viticult. 45:388-392.

Wample, R. L., G. Reisenauer, A. Bary, and F. Schuetze. 1990. Microcomputercontrolled freezing, data acquisition and analysis system for cold hardiness evaluation. HortScience 25:973-976.

Wample, R.L., S.E. Spayd, R.G. Evans, and R.G Stevens. 1993. Nitrogen fertilization of White Riesling grapes in Washington: nitrogen seasona effects on bud cold hardiness and carbohydrate reserves. Amer. J. Enol. Viticult. 44:159-167.

Weaver, R.J. 1952. Thinning and girdling of Red Malaga grape in relation to size of berry, color, and percentage of total soluble solids of fruit. Proc. Amer. Soc. Hort. Sci. 60:132-141.

Weaver, R.J. 1953. Further studies on effects of 4-chlorophenoxyacetic acid on development of Thompson seedless and Black Corinth grapes. Proc. Amer. Soc. Hort. Sci. 61:135-143.

Weaver, R.J. 1954. Preliminary report on thinning grapes with chemical sprays. Proc. Amer. Soc. Hort. Sci. 63:194-200.

Weaver, R.J. 1976. Grape growing. Wiley Interscience, John Wiley \& Sons, New York.

Weaver, R.J. and R.M. Pool. 1969. Effect of ethrel, abscisic acid, and a morphactin on flower and berry adscission and shoot growth in Vitis vinifera. J. Amer. Soc. Hort. Sci. 94:474-478.

Weaver, R.J. and R.M. Pool. 1968. Induction of berry abscission in Vitis vinifera by morphactins. Amer. J. Enol. Viticult. 19:121-124

Webster, J.E. and F.B. Cross. 1938. Composition of grape leaves in relation to uneven coloring of Concord grapes. Proc. Amer. Soc. Hort. Sci. 36 494-495 (abstr.).

Webster, J.E. and F.B. Cross. 1935a. Chemical analysis of grape juices - Variety comparisons. Proc. Amer. Soc. Hort. Sci. 33:442-443.

Webster, J.E. and F.B. Cross. 1935b. Use of the refractometer in studying sugar content of grape juices. Proc. Amer. Soc. Hort. Sci. 33:444-446.

Webster, J.E. and F.B. Cross. 1936. The composition of grape juice as affected by the method of vine training. Proc. Amer. Soc. Hort. Sci. 34:405-474.

Wellington, R. 1932. Results obtained from crosses between Danugue (Gros Guillaume) and Ontario and Hubbard grape varieties. Proc. Amer. Soc. Hort. Sci. 29:137-138.

Wellington, R. 1936. Breeding hardy Muscat grapes. Proc. Amer. Soc. Hort Sci. 34:421-425.

Wiggans, C.B. 1926. A study of the relative value of the fruiting shoots arising from primary and secondary buds of Concord grape. Proc. Amer. Soc. Hort. Sci. 23:293-296.

Williams, L.E. and R.J. Smith. 1991. The effect of rootstock on the partitioning of dry weight, nitrogen and potassium, and root distribution of Cabernet Sauvignon Grapevines. Amer. J. Enol. Viticult. 42:118-122.

Williams, W.O. 1951. Comparison of the effects of spray weed control of summer covercrop and of clean tillage on the grape vine, its fruit, and on the soil. Proc. Amer. Soc. Hort. Sci. 58:136-140.

Winkler, A.J. 1927. Improving of fruiting of the Muscat (of Alexandria) grape by less severe pruning. Proc. Amer. Soc. Hort. Sci. 24:157-163.

Winkler, A.J. 1928. Berry thinning of grapes. Proc. Amer. Soc. Hort. Sci. 25 220-223.

Winkler, A.J. 1930. The relation of number of leaves to size and quality of table grapes. Proc. Amer. Soc. Hort. Sci. 27:158-160.

Winkler, A.J. 1932. The lateral movement of elaborated foods in the grape vine Proc. Amer. Soc. Hort. Sci. 29:335-338.

Winkler, A.J. 1933. The treatment of frosted grape vine. Proc. Amer. Soc. Hort Sci. 30:253-257.

Winkler, A.J. 1965. General viticulture. Univ. Calif. Press, Berkeley.

Wolf, T.K. and M.K. Cook. 1994. Cold hardiness of dormant buds of grape cultivars: comparison of thermal analysis and field survival. HortScience 29:1453-1455.

Wolfe, D and G.R. Brown. 1986. Susceptibility of young table grape cultivars to winter injury. HortScience 4:93.

Wolpert, J.A. and G.S. Howell 1985. Cold hardiness of Concord grapevines. I. Variation in cold hardiness within the canopy. Amer. J. Enol. Viticult. 36:185-188

Wolpert, J.A.and G.S Howell. 1984. Effects of cane length and dormant season pruning date on cold hardiness and water content of Concord bud and cane tissues. Amer. J. Enol. Viticult. 35:237-241.

Woodroof, J.G. 1934. Five strains of the Scuppernong variety of Muscadine grapes. Proc. Amer. Soc. Hort. Sci. 32:384-385.

Xu, H. and A.T. Bakalinsky. 1996. Identification of grape (Vitis) rootstocks using sequence characterized amplified region DNA markers. HortScience $31: 267-268$

Xue, B., K.S. Ling, C.L. Reid, S. Krastanova, M. Sekiya, E.A. Momol, S. Sule, J. Mozsar, D. Gonsalves, and T.J. Burr. 1999. Transformation of five grape rootstocks with plant virus genes and a virE2 gene from Agrobacterium tumefaciens. In Vitro Cellular Dev. Biol. - Plant 35:226-231.

Yeager, A.F. 1936. Breeding hardy grapes. Proc. Amer. Soc. Hort. Sci. 34: 414-415. 